\title{
THE TAXATION SYSTEM OF UKRAINE: STATE OF AFFAIRS AND PROSPECTS OF REFORMING
}

\section{Dmytro Mishchenko}

\section{INTRODUCTION}

The result of reforms, introduced in Ukraine during the independence period became fundamental socioeconomic transformations. Along with that the inconsistency of reforming processes, the absence of entire concept of national economic policy, substantial structural disparities in the economy led to the deep and sustained socioeconomic crisis of society. One of the main reasons for the intensification of the crisis phenomena in Ukraine was the undeliberate tax policy of the state, which resulted in the restraint of innovation and investment processes, which then leads to the insufficient payment by budgets of tax revenues of all levels. Considering the constant deficit of the state budget of Ukraine, the lack of financial resources to fulfill the socioeconomic functions of the state, the emergence of additional financial needs due to aggravation of geopolitical, social and financial crises, improvement of tax policy in Ukraine is an important factor in improving the competitiveness of the national economy. Despite certain progress in the reform of Ukraine's tax system in recent years, it still does not provide adequate encouragement for investment inflows and innovative economic development.

Writings of many Ukrainian researches are dedicated to the issues under investigation, among them: O.Ya. Bozulenko, T.A. Vasilyeva, O.M. Desyatnyuk, Y.B. Ivanov, V.M. Kmit, A.I. Krisovatyi, S.V. Leonov, T.V. Merkulova, N.S. Pedchenko, I.V. Ped, K.P. Proskura, O.V. Revenko, D.M. Serebryanskyi, O.O. Suntsova, S.V. Sluhai, T.V. Tuchak, I.O. Cymbalyuk, T.V. Chumakova, K.I. Shvabiy, I.M. Shkola and others. Despite the increased academic interest to the problem of tax system development 
and the considerable amount of scientific research results in this field, there is still no integrated approach to its solution.

To achieve a successful economic advancement is possible upon condition of a strong, sound financial capability, the basis of which is budget incomes as well as tax revenues. A legal framework, regulating tax collection and administrative bodies, controlling the implementation of legislation by economic entities have been developed in Ukraine, but it is impossible to say that the tax system is efficient and reaches its functional purpose.

The tax and budget systems have always been and will be subjected to criticism, as they must be based on mechanisms for overcoming many social and personal contradictions. It is almost impossible to achieve optimality in their resolving. Especially since the economy is at different stages of development (ramp-up, peak, contraction, crisis) in each period, depending on which the contents of both tax and budgetary policies differ, exacerbating the mentioned contradictions and increasing the social tensions regarding the assessment of fairness and efficiency of the system (first of all, in relation to the taxation: between the state, on the one hand, and business entities and the population as taxpayers, on the other).

In fact, such a state of affairs often leads to violation of certain, even universally recognized, principles of fiscal policy, such as fairness, efficiency, stability.

\section{Analysis of the state of affairs of Ukrainian taxation system}

One of the major purposes of the national financial policy is the implementation of effective taxation system.

The taxation system is a set of taxes established in the country that are interconnected, complement each other and do not contradict the system as a whole and its other elements ${ }^{1}$.

V. Vyshnevskyi characterizes the taxation system not only as a set of tax laws but also as an institution that includes a specific social

1 Курносова К.В. Напрями реформування доходної бази місцевого самоврядування. Наукові праці НДФІ. 2007. 3(40). С. 25-33. 
layer of financial specialists, rules and traditions of accounting, established by the state fiscal and financial institutions, formal and informal procedures related to the calculation, payment and distribution of statutory payments ${ }^{2}$.

One of the significant factors in ensuring the growth of the country's economy is an effective taxation system and a tax mechanism that is functioning and regulated by the tax legislation.

The role of the tax mechanism resides in the fact that it allows rationalizing tax relations, basing on tax law and the tax assessment governance.

From the perspective of functional content, the essence of the tax mechanism can be formulated as follows: it is a set of financial and budget spheres of activity, which interact with each other and are regulated by specific legislative and legal norms of the state, and determine the establishment, assessment of planned, actual and forecast tax liabilities of the subjects of tax legal relations, implementation of scientifically substantiated actions on the current interference in the process of budget performance of the country, both stimulating (tax regulation) and sanction measures of influence in violation of tax legislation (tax control).

The tax mechanism can be considered as a certain way of functioning of its elements in the tax management system, through which the economic interests of the subjects of tax relations are realized. Among the features which are peculiar to tax mechanism of our state, scientists separate the following: fiscal and redistributive; control function; planning function; regulation function; supervising function; coercive function; information function; advisory function.

The components of the tax mechanism at the macro and microeconomic levels have some differences, as follows:

2 Вишневський В., Вєткін А. Відхід від сплати податків: теорія і практика. Донецьк: Монографія IНАН України, Інститут економіки промисловості, 2003. 62 с. 
- The subject of implementation of the tax mechanism at the macroeconomic level is the state, and at the microeconomic level is the economic entity.

- The object of control at the macroeconomic level is budget system tax revenues, and at the microeconomic level is a complex of tax liabilities and taxpayers' tax payments. Although these objects are closely related, there is also an indirect interinfluence.

Having regard to the above said, it is necessary to pay attention to one of the main components of the functioning of the tax system, to the concept of "taxes".

With the help of taxes, the gross domestic product is redistributed and the business activity of members of society is affected, market self-regulation is changing, the state policy of economic development is implemented. Taxes are an objective social phenomenon, so when constructing a tax system, it is necessary to proceed from the realities of the socioeconomic state of the country, and not be guided by desiderates, even if the best, but unenforceable ones.

The tax is a complex economic category that characterizes the economic relations between the state and members of society that arise in the process of distributing GDP for the removal of a part of gross national income and redistribution by the state with the aim of financing government expenditures ${ }^{3}$.

According to the Tax Code of Ukraine, tax is a mandatory, unconditional payment to the appropriate budget, which is paid by taxpayers ${ }^{4}$.

Therefore, the tax has legal, economic and social characteristics. The legal content of taxes is manifested through a system of legal rules. Taxes are established exclusively by the state in accordance with the law by legally enforceable rules. In the implementation of the

${ }^{3}$ Малишкін О. I. Коефіцієнт податкового навантаження на мікрорівні: розрахунок та застосування Бухгалтерський облік і аудит. 2015. № 1. С. 18-25.

${ }^{4}$ Податковий кодекс України: Закон України від 02.12.2010 № 2755-VI URL: https://zakon.rada.gov.ua/laws/show/2755-17 
essence of tax as a legal category, the basis is the change of ownership that means the transfer of property to the state and its appliance in order to meet social needs.

In economic terms, taxes are an instrument of state distribution and redistribution of income and financial resources.

The social content of taxes gives the state the opportunity to influence the sphere of economic relations in society.

The tax system forms the basis of the functioning of any modern state. It is a collection of taxes, fees, and other required payments, contributions to the budget and government trust funds that operate in due process of law.

In a more comprehensive sense, the tax system is governed by the rules of financial law, enshrined in laws and regulations concerning tax liabilities, a set of tax relations mediated by financial institutions that provide tax administration and manifest in specific forms of taxation ${ }^{5}$.

The state through the budget ensures the raising of funds needed to ensure the socioeconomic development of the country and use them for the purpose of fulfilling its functions, which are entrusted on the budget institutions and spending units. At that, the essential part of gross domestic product accumulates within the consolidated budget and is used to ensure the economic development of the country, to solve social problems, to pay state administration bodies, and to ensure defense capacity.

The economic conditions of the country, and accordingly the level and dynamics of tax revenues need continuous monitoring and research in order to prevent adverse effects on the country's development. Let's further analyse the structure of actual tax revenues for general and special funds of the Consolidated Budget of Ukraine.

5 Макогон В.Д. Формування доходів місцевих бюджетів у зарубіжних країнах. Наукові праџฺі НДФІ. 2008. № 1 (42) С. 56-66. 
Table 1

Composition and dynamics of tax revenues of the Consolidated Budget of Ukraine, UAH billion ${ }^{6}$

\begin{tabular}{|l|c|c|c|c|}
\hline & $\mathbf{2 0 1 6}$ & $\mathbf{2 0 1 7}$ & $\mathbf{2 0 1 8}$ & $\begin{array}{c}\text { Absolute } \\
\text { variation 2018 } \\
\text { from 2016 (+,-) }\end{array}$ \\
\hline General fund & 645,13 & 791,36 & 943,678 & 298,548 \\
\hline Special fund & 5,65 & 36,79 & 42,68 & 37,03 \\
\hline Total & 650,78 & 828,15 & 986,358 & 335,578 \\
\hline
\end{tabular}

In 2018, tax revenues of the general fund of the Consolidated Budget of Ukraine increased by UAH 298.55 billion compared to 2016. Tax revenues of the special fund of the Consolidated Budget of Ukraine increased by UAH 37.03 billion. In total, the tax revenues of the Consolidated Budget of Ukraine increased by UAH 335.57 billion.

In the modern world, the basis of fiscal policy is the tax policy of the state, which effectiveness depends on the socioeconomic development of the country. The Ukrainian realities in this respect show that in recent years the central focus of tax policy has been on taxation of consumption taxes, which provide about $55 \%$ of the Consolidated budget tax revenues.

Table 2

Structure of tax revenues of the Consolidated Budget of Ukraine, UAH billion

\begin{tabular}{|l|c|c|c|c|}
\hline & $\mathbf{2 0 1 6}$ & $\mathbf{2 0 1 7}$ & $\mathbf{2 0 1 8}$ & $\begin{array}{c}\text { Absolute } \\
\text { variation 2018 } \\
\text { from 2016 (+,-) }\end{array}$ \\
\hline General fund & 99,13 & 95,56 & 95,67 & $-3,46$ \\
\hline Special fund & 0,87 & 4,44 & 4,33 & 3,46 \\
\hline Total & 100 & 100 & 100 & \\
\hline
\end{tabular}

6 Виконання Державного бюджету / сайт Державної казначейської служби України URL: http://www.treasury.gov.ua/maitalog/list?Currdir=311513 
In 2018, the interest of tax revenues of the general fund of the Consolidated Budget of Ukraine decreased by 3.46 percentage points compared to 2016. Accordingly, the tax revenues of the special fund of the Consolidated Budget of Ukraine have increased.

Tax revenues take the lead among the various methods of mobilization of budgetary resources and instruments of state regulation of the economy. They are the most adequate and objective reflection of the state of the national economy. The use of taxes as financial leverages is based on the introduction of various instruments for regulating economic proportions, providing the necessary level of social safety nets and so on. For any country that has market-based economy, taxes are a kind of leverage to regulate and prevent negative economic trends. Taxes are a particular mechanism that provides a link between national interests and the interests of individual entities.

It is taxes that determine the nature of the relationship between enterprises of all forms of ownership with the state and local budgets, with banking institutions, state executive bodies, etc ${ }^{7}$.

Table 3

Composition of tax revenues of the general fund of the Consolidated Budget of Ukraine, billion UAH

\begin{tabular}{|l|c|c|c|c|}
\hline \multicolumn{1}{|c|}{$\mathbf{1}$} & $\mathbf{2 0 1 6}$ & $\mathbf{2 0 1 7}$ & $\mathbf{2 0 1 8}$ & Variation, \% \\
\hline Tax revenues & $\mathbf{2}$ & $\mathbf{3}$ & $\mathbf{4}$ & $\mathbf{5}$ \\
\hline $\begin{array}{l}\text { Income taxes, profits } \\
\text { taxes, market gains taxes }\end{array}$ & 645,13 & 791,36 & 943,67 & 146,28 \\
\hline Property taxes & 0,00 & 256,09 & 334,95 & 168,31 \\
\hline $\begin{array}{l}\text { Rental taxes and } \\
\text { payments for the use } \\
\text { of other environmental } \\
\text { resources }\end{array}$ & 46,61 & 51,13 & 49,91 & 107,08 \\
\hline
\end{tabular}

7 Жиляєва Н. Фіскальна політика держави в період світової економічної кризи та напрями підвищення її ефективності. Вісник Київського національного університету ім. Тараса Шевченко. 2010. № 119. С. 49-51. 
End of table 3

\begin{tabular}{|l|c|c|c|c|}
\hline \multicolumn{1}{|c|}{$\mathbf{1}$} & $\mathbf{2}$ & $\mathbf{3}$ & $\mathbf{4}$ & $\mathbf{5}$ \\
\hline $\begin{array}{l}\text { Domestic taxes on } \\
\text { goods and services }\end{array}$ & 337,26 & 422,16 & 474,92 & 140,82 \\
\hline $\begin{array}{l}\text { Taxes on international } \\
\text { trade and external } \\
\text { transactions }\end{array}$ & 20,37 & 22,90 & 23,82 & 116,94 \\
\hline $\begin{array}{l}\text { Fees for fuel and } \\
\text { energy resources }\end{array}$ & 0,28 & $-0,01$ & $-0,01$ & $-2,14$ \\
\hline Local taxes & 42,26 & 52,59 & 61,03 & 144,42 \\
\hline Other taxes and charges & $-0,66$ & $-13,50$ & $-0,95$ & 143,94 \\
\hline
\end{tabular}

The general fund of the Consolidated Budget of Ukraine in 2018, funded with the money coming from the tax revenues, got by $46.28 \%$ more than in 2016.

Tax revenues, income taxes, market gains taxes, local taxes, domestic taxes on goods and services, as well as taxes on international trade and external transactions were characterized by substantial growth of the tax revenues of the general fund of the Consolidated Budget of Ukraine.

In market economy conditions, tax revenues to the state and local budgets are essential for the state to fulfill its functions and the main structure-forming component of the revenue part of the budgets. Table 4 summarizes the tax revenues of the special fund of the Consolidated Budget of Ukraine. Presently, in Ukraine, the tax sharing between the state and local budgets is such that, first, it does not promote the self-sufficiency of local authorities and financial independence from the state, and secondly, there is an excessive withdrawal of tax revenues from the regions and as the consequence there is a need for transfer regulation.

To the Special Fund of the Consolidated Budget of Ukraine, the largest amount of tax revenues in 2018 came from domestic taxes on goods and services. Revenues from taxes on international trade and 
external transactions over a space of three years increased by UAH 3.26 billion.

Table 4

Composition of tax revenues of the special fund of the Consolidated Budget of Ukraine, billion UAH

\begin{tabular}{|c|c|c|c|c|}
\hline & 2016 & 2017 & 2018 & $\begin{array}{c}\text { Absolute } \\
\text { variation } \\
2018 \text { from } \\
2016(+,-) \\
\end{array}$ \\
\hline Tax revenues & 5,690 & 36,79 & 42,69 & 37,00 \\
\hline $\begin{array}{l}\text { Income taxes, profits } \\
\text { taxes, market gains } \\
\text { taxes }\end{array}$ & & 2,990 & 1,15 & 1,15 \\
\hline Property taxes & 0,011 & 0,001 & 0,00 & $-0,01$ \\
\hline $\begin{array}{l}\text { Rental taxes and } \\
\text { payments for the use of } \\
\text { other environmental } \\
\text { resources }\end{array}$ & & & 0,18 & 0,18 \\
\hline $\begin{array}{l}\text { Domestic taxes on } \\
\text { goods and services }\end{array}$ & & 13,270 & 32,24 & 32,24 \\
\hline $\begin{array}{l}\text { Taxes on international } \\
\text { trade and external } \\
\text { transactions }\end{array}$ & & 1,640 & 3,26 & 3,26 \\
\hline $\begin{array}{l}\text { Separate local taxes } \\
\text { and fees }\end{array}$ & & & & 0,00 \\
\hline $\begin{array}{l}\text { Fees for fuel and } \\
\text { energy resources }\end{array}$ & & & & 0,00 \\
\hline Local taxes & $-0,001$ & 0,694 & & 0,00 \\
\hline $\begin{array}{l}\text { Other taxes and } \\
\text { charges }\end{array}$ & 5,680 & 18,190 & 5,87 & 0,19 \\
\hline
\end{tabular}




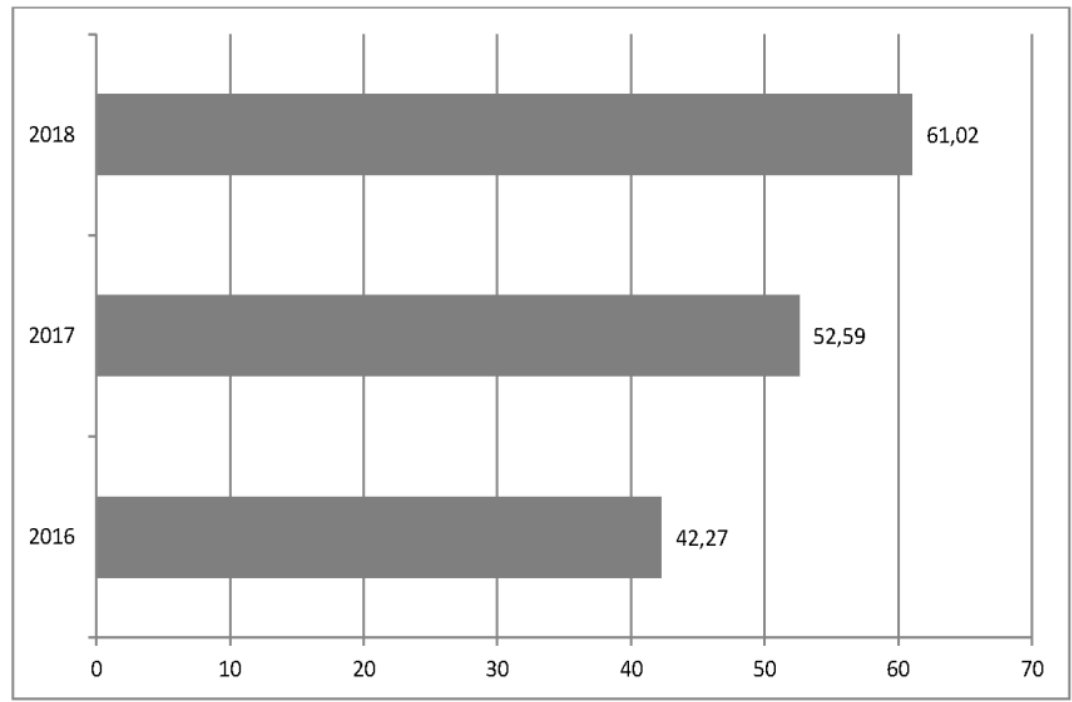

Fig. 1. Dynamics of local taxes in the general fund revenues of the Consolidated Budget of Ukraine, billion UAH

The economic and social development of any country depends largely on the development of its territories. This, in turn, requires adequate financial support through the formation of local budgets. Securing local government with stable and sufficient financial resources is the key to becoming a capable and efficient local authority. Moreover, without the financial autonomy of local budgets with its numerous components and taking into account the tax potential of each territory, it is impossible to build and develop an effective national economy ${ }^{8}$.

As a part of the general fund of the Consolidated Budget of Ukraine, revenues from local taxes have steadily increased over the three-year period. In 2018, their total amount was higher than in 2016 by UAH 18.75 billion.

${ }^{8}$ Податкова система: Навчальний посібник за заг. ред. І. С. Волохової, О. Ю. Дубовик. Харків: Видавництво «Діса плюс», 2019. 402 с. 
Table 5

Dynamics of local taxes of the general fund of the Consolidated

Budget of Ukraine, billion UAH

\begin{tabular}{|c|c|c|c|c|}
\hline & 2016 & 2017 & 2018 & $\begin{array}{c}\text { Absolute } \\
\text { variation } \\
2018 \text { from } \\
2016(+,-)\end{array}$ \\
\hline Property tax & 24,99 & 29,06 & 31,27 & 6,28 \\
\hline $\begin{array}{l}\text { Parking service fees } \\
\text { for vehicles }\end{array}$ & 0,07 & 0,08 & 0,10 & 0,03 \\
\hline Tourist tax & 0,05 & 0,07 & 0,09 & 0,04 \\
\hline $\begin{array}{l}\text { Fee for conducting } \\
\text { certain types of } \\
\text { business activities, } \\
\text { which is to be paid } \\
\text { before } 1 \text { January } 2015\end{array}$ & $-0,01$ & $-0,01$ & 0,00 & 0,01 \\
\hline Single tax & 17,17 & 23,39 & 29,56 & 12,39 \\
\hline Total & 42,27 & 52,59 & 61,02 & 18,75 \\
\hline
\end{tabular}

Revenues from the single tax to the general fund of the Consolidated Budget of Ukraine during 2016-2018 increased by UAH 12.39 billion. The increase in property tax revenues was also significant, which increased by UAH 6.28 billion.

Negative factors affecting the dynamics of local budget revenues are a slowdown of socioeconomic development of the country, rise in unemployment, the aggravation of inflation, the devaluation of the national currency, which have been recently observed in the country. In case of maintaining the heightened rates of growth of spending on government sector financing, lying under local authority's cognizance, the problem of revenue instability is very acute. 
Table 6

Structure of local taxes of the general fund of the Consolidated Budget of Ukraine, billion UAH

\begin{tabular}{|l|c|c|c|c|}
\hline \multicolumn{1}{|c|}{ from } & $\mathbf{2 0 1 6}$ & $\mathbf{2 0 1 7}$ & $\mathbf{2 0 1 8}$ & $\begin{array}{c}\text { Absolute } \\
\text { variation } \\
\mathbf{2 0 1 8} \text { from } \\
\mathbf{2 0 1 6}(+,-)\end{array}$ \\
\hline Property tax & 59,12 & 59,12 & 55,26 & $-3,87$ \\
\hline $\begin{array}{l}\text { Parking service fees } \\
\text { for vehicles }\end{array}$ & 0,15 & 0,16 & 0,15 & 0,00 \\
\hline Tourist tax & 0,14 & 0,13 & 0,13 & $-0,01$ \\
\hline $\begin{array}{l}\text { Fee for conducting } \\
\text { certain types of } \\
\text { business activities, } \\
\text { which is to be paid } \\
\text { before 1 January 2015 }\end{array}$ & $-0,03$ & $-0,03$ & $-0,01$ & 0,02 \\
\hline Single tax & 40,62 & 40,62 & 44,48 & 3,86 \\
\hline Total & 100 & 100 & 100 & 0,00 \\
\hline
\end{tabular}

The analysis of the structure of local tax revenues to the general fund of the Consolidated Budget of Ukraine shows that in 2018, $99.74 \%$ of these revenues were ensured at the cost of property tax and single tax. At the same time, the relative share of tax funds from the property tax decreased by $3.87 \%$, and from the single tax increased by $3.86 \%$.

\section{Determination of development prospects of Ukrainian taxation system}

The issue of local taxation is an important tool for the functioning and development of local government. As successful performance of functions and tasks entrusted to local governments is impossible without adequate financial support. The major source of 
revenues of local budgets should become own revenues, including local taxes and fees. That is why, the enhancement of the role of local taxes and fees and increase of their interest in composition of revenues is the principal direction of stabilization of local budgets and extension of the financial autonomy of the respective territories.

The local tax system should not only meet the needs of local budgets in the flow of funds, but also take into account the solvency margin of potential payers of taxes and fees. Consequently, in establishing the rates of local taxes and fees, and when introducing favorable terms of their levying, it should be simultaneously taken into account both aspects in their inextricable connection.

The peculiarity of the tax system in Ukraine in general and of the local tax system, in particular, is its inconsistency, which is primarily due to the instability of tax legislation. Consequently, in establishing taxes and fees at the local level, the authorities should take this specific feature into account and implement the principle of maximum mobility and flexibility ${ }^{9}$.

To increase the role of local taxes and fees, it is necessary to focus on a number of problems that exist in the local budgeting system. For example, they include an excess of administrative expenditures compared to revenues in such budgets, limitation of local authorities' ability to set and pay local taxes and fees, and the complexity of the taxation process. Well-organized local budgeting will promote the development of the region's well-being and improve the quality of life of the population, so studying the place of local taxes and fees plays an important role in developing a fair and efficient tax system in the country in accordance with the principles of a democratic system.

In recent years, changes in tax and budget legislation towards increase in income volume of local budgets at the expense of local taxes and fees have been implemented using methods such as

9 Динаміка податкового навантаження в Україні в контексті реалізації податкової реформи / за заг. ред. Т.І.Єфименко, А. М. Соколовскої. К.: ДННУ «Академія фінансового управління», 2013. 492 с. 
eliminating inefficient taxes and introducing new ones; extending taxable items; change in tax rates; widening the circle of taxpayers; tax regrouping (transfer of national taxes (single tax and land fee)) to the local level.

The main budget-forming local taxes in Ukraine have become a single tax and land fee. However, the disadvantages of the local taxation system are the low fiscal importance of local taxes and fees, the lack of legal bases for the functioning of the self-taxation system, the absence of a targeted local taxation system.

The national tax system in composition and structure is similar to the systems of developed European countries, since the tax issues are developed in accordance with the rules of European tax legislation, as well as aspects of GATT / WTO tax policy and other international economic organizations. However, unlike the countries of the European Community, the tax system of Ukraine is not an instrument of increasing the competitiveness of the state. It does not contribute to the growth of economic activity of incorporated and unincorporated businesses.

In the process of reforming the tax system in Ukraine, not only the level of tax burden but also the optimal combination of direct and indirect taxes is an important problem. If during the economic slack the role of indirect taxes is increasing, which makes it possible to consolidate and stabilize the tax base, then, during economic growth, on the contrary, the direct taxes have a dominant fiscal influence ${ }^{10}$.

Direct taxes are the basis of the tax systems of countries with advanced market economies because they have significant advantages over indirect ones. As it is well-known, direct taxes have almost no effect on prices, do not change the structure of demand, but reduce the income of payers and thus affect the volume of investment and consumer demand. The direct correlation between the amount of direct taxes and the amount of income contributes to increasing the state's

${ }^{10}$ Дубовик О. Ю. Гармонізація податкових систем в умовах глобалізації. Фінансова система України: проблеми та перспективи розвитку в умовах трансформації сочіально-економічних відносин. Севастополь, 2013. С. 25-27. 
ability to regulate economic processes and solve social justice at the expense of progressive tax rates. At the same time, direct taxes in fiscal terms are inferior to indirect taxes in the stability of revenues, in the uniform distribution of revenues in individual regions, in the existence of more favourable conditions for tax evasion. Indirect taxes, while more convenient for fiscal authorities from the standpoint of their levying, but their payment is burdensome on shoulders of the final consumer, so the prevalence of fair direct taxes will avoid such negative effects as impoverishment of the majority of the population, further decline in domestic production. The practice of developing tax systems in European countries testifies to the growing role of direct taxation, first and foremost, of income taxation of revenues. The growing tax culture and the awareness of direct taxpayers make it possible to ensure a steady flow of budget revenues and to use taxes as tools to stimulate scientific and technological progress, to increase employment, and even territorial development and so on. Nowadays, indirect taxes prevail in Ukraine, since in the conditions of low level of income of individuals and inadequate level of tax culture it is impossible to ensure that the structure of the tax system of direct taxes dominates. At the same time, national tax rates on personal income and corporate income tax are among the lowest in Europe, which should be an important prerequisite for attracting foreign investments, creating new jobs and increasing business activity.

In spite of the fact that during 2012-2018 Ukraine has improved its rating on the simplicity of the tax system, the national tax system remains complex and unfavourable for doing business. Local businesses are required to spend much more time (327.5 hours) in preparing and filing tax returns and paying taxes than in EU countries.

In terms of this, Ukraine is in the 159th place in the world, where the average time for preparation of reporting is 240 hours, when in EU countries it is 161 hours. According to the report of the Business Ombudsman Council, in 2016, 868 complaints were received from companies against the work of state bodies, and the largest number (49\%) of complaints from Ukrainian business were received regarding the work of the State Fiscal Service bodies. The low level of trust to 
the fiscal authorities is evidenced by the results of a survey conducted by the TNS Research Company commissioned by the National Reform Council's Project Office, according to which only $17 \%$ of citizens trust the employees of the State Fiscal Service. What is more, according to the results of a monthly poll by this company, $72 \%$ of citizens surveyed did not feel the positive fallout from tax reforms ${ }^{11}$. The level of tax burden in Ukraine is assessed in diverse ways. Almost all investment climate experts find it unfavourable because the taxation of the real sector of economy is overburdensome. It suppresses the processes of economic reproduction, and the enterprise can operate at a profit, usually only with the concealment of its income from taxation. The majority of entrepreneurs also believe that the current economic situation in our country does not contribute to the development of entrepreneurial activity, that the heavy burden of taxes leads to such negative consequences as the decline of business activity of business entities, shadowing economy, the outflow of national capital abroad. As a result, budget revenues are reducing and social tensions are increasing in society. In fact, today the taxation system is one of the main obstacles to the effective competitive development of our country's economy.

In order to ensure the development of national economy and growth of well-being of the citizens, the taxation system of Ukraine must change considering the national and international experience, the demands of time and priorities of national economy development.

Significant shortcomings in the functioning of the national taxation system include the suboptimal correlation of direct and indirect taxes, the imperfection of the legal framework, complex procedures for tax administration and non-transparent control of their application, insufficient work of tax authorities. Improving the efficiency of Ukraine's taxation system requires strengthening of the stimulating role of direct taxes; simplifying tax administration

11 Ярема Б.П., Ролько А.В. Сучасна податкова система України: проблеми та перспективи розвитку. Причорноморські економічні студіï. 2018. Випуск 34. С. 171-175. 
procedures and increasing transparency in control of their appliance; increasing the efficiency of work of controlling bodies with strengthening of control over taxpayers ${ }^{12}$.

The main provisions, which should be taken into account in the process of the further development of Ukrainian taxation system, are as follows: the taxation system must have an investment and social orientation; changes in the taxation system should be made in parallel with reforms in the system of remuneration, pensions, improvement of the social sphere; expanding the use of non-tax forms and methods of mobilizing budget revenues; the tax taxation should be based on direct taxes; indirect taxes should be used only in the form of excise duties to limit the consumption of certain types of goods, the ability of the manufacturer-monopolist to obtain unreasonably high incomes, as well as to imposition of taxation to luxury commodities and protect his own manufacturer; the list of taxes for environmental pollution, such as littering public places, needs to be increased; the taxation system must meet the requirements of simplicity, transparency and plainless; the tax must be charged at a convenient time for the payer and in an appropriate way; extending the rights of self-governing bodies in the field of taxation ${ }^{13}$.

It should be noted that in the process of reforming the taxation system in Ukraine, an important problem is not only the level of tax burden, but also the optimal combination of direct and indirect taxes. While indirect taxes are convenient for fiscal authorities to collect, they are burdensome for the final user. That is why, the prevalence of proper direct taxes will avoid the negative consequences, such as the decline in the standard of living of the population, the further decline of Ukrainian production, which is not able to compete with the

12 Радова О.В. Оподаткування в Україні: нововведення, тенденції та проблеми розвитку. Науковий вісник Ужгородського національного університету. 2018. Випуск 20, частина 3.

13 Щербань О.Д. Напрями удосконалення формування доходів місцевих бюджетів. Вісник економіки транспорту і промисловості. 2013. № 41. С. 74-79. 
products of foreign producers ${ }^{14}$. The main task of reforming the taxation system should be the creation of the preconditions for economic growth by unlocking entrepreneurial potential and the facilitation of implementation of the national competitive advantages. At the structural level, the reform should facilitate accelerated economic recovery by accelerating the process of growth of new businesses and industries. Regulation of modern economic relations in Ukraine requires a flexible tax policy of the state that would allow optimally linking the interests of the state with the interests of entrepreneurship. Reforms that reduce tax pressures on household incomes can also help to bring in some income of individuals from the cold and more effectively differentiate taxpayers. In order to create an optimal taxation system, it is necessary to be guided by such basic principles as social justice, economic efficiency, stability and flexibility. Therefore, the prospects for further positive changes in the taxation system are the specification of measures to reform Ukraine's tax policy to reduce the tax burden, simplification of tax administration procedures and improvement of the tax control mechanism.

\section{CONCLUSIONS}

Reforming the taxation system begins with the competent introduction of principle of taxation, the tax legislation must be constructed hereon. To disrupt and form new regulatory framework is not practical, it is necessary to make allowances in accordance to the changes in tax area. Current tax law can be described as contradictory and unsustainable. The reforming taxation system of Ukraine should take the form of an optimal combination of fiscal efficiency and regulatory mechanisms for economic growth, reflected in the principles of taxation. Key directions of modernization of the existing tax system should be reduced to: modulated reduction and equalization of tax pressure between payers of different categories without taking

14 Крисоватий А.І. Теоретико-організаційні домінанти та практика реалізації податкової політики в Україні. Тернопіль: Карт-бланш, 2015. 371 с. 
into account their type of activity; introduction of unfailing monitoring of the expenditure level at manufacturing enterprises; creation of an enabling tax environment for the active involvement of foreign investors; cost reduction for the administrative component of taxation; streamlining tax rates and levelling them to European standards. The reforming the taxation system should be based on the principle of fiscal efficiency, in other words the formation of the revenue at the appropriate level, which will ensure the fulfillment of its functions by the state; achieving equal tax burdens, equal tension between taxpayers, social justice, stability and flexibility are the key to the efficiency of the taxation system. A balance of these indicators will allow ensuring the economic growth of Ukraine not only at a certain stage, but also in the long run. Thus, the effectiveness of the taxation system is reflected through the application and operation of a tax mechanism that takes into account the specific economic situation in the country and the role of the state in regulating social and economic processes. In order to achieve the effectiveness of tax regulation of the economy, a mechanism for using specific tax forms and management methods should be developed. Adoption of the Tax Code of Ukraine contributed to the reduction of tax pressure by abolishing unreasonable benefits and broadening of the tax base. It, in its turn, increased budget revenues, as well as enabled solving complex social issues.

\section{SUMMARY}

This paper presents the conducted analysis of the contemporary state of tax revenues of consolidated budget of Ukraine. It is determined that to ensure the development of the state economy and growth of well-being of the country, the Ukrainian taxation system should be changed, taking into consideration the local and global experiences, the demands of times and national economy development priorities. It is established that the current tax legislation may be defined as contradictory and unsustainable. Reforming the taxation system of Ukraine should be presented in the form of an optimal combination of fiscal efficiency and control mechanisms for economic growth, reflected in the principles of taxation. Key directions of 
modernization of the existing tax system should be reduced to: modulated reduction and equalization of tax pressure between payers of different categories without taking into account their type of activity; introduction of unfailing monitoring of the expenditure level at manufacturing enterprises; creation of an enabling tax environment for the active involvement of foreign investors; cost reduction for the administrative component of taxation; streamlining tax rates and levelling them to European standards.

\section{REFERENCES}

1. Курносова К.В. Напрями реформування доходної бази місцевого самоврядування. Наукові пращуі НДФІ. 2007. 3(40). C. 25-33.

2. Вишневський В., Вєткін А. Відхід від сплати податків: теорія і практика. Донецьк: Монографія ІНАН України, Інститут економіки промисловості, 2003. - 10, 62 с.

3. Малишкін О. I. Коефіцієнт податкового навантаження на мікрорівні: розрахунок та застосування. Бухгалтерський облік $i$ aудит. 2015. № 1. С. $18-25$.

4. Податковий кодекс України: Закон України від 02.12.2010 № 2755-VI URL: https://zakon.rada.gov.ua/laws/show/ 2755-17

5. Макогон В.Д. Формування доходів місцевих бюджетів у зарубіжних країнах. Наукові праизі НДФІ. 2008. № 1 (42) С. 56-66.

6. Виконання Державного бюджету / сайт Державної казначейської служби України URL: http://www.treasury.gov.ua/ maitalog/list?Currdir=311513

7. Жиляєва Н. Фіскальна політика держави в період світової економічної кризи та напрями підвищення іï ефективності. Вісник Київського національного університету ім. Тараса Шевченко. 2010. № 119. С. 49-51.

8. Податкова система: Навчальний посібник за заг. ред. I. С. Волохової, О. Ю. Дубовик. Харків: Видавництво “Діса плюс", 2019. 402 с. 
9. Динаміка податкового навантаження в Україні в контексті реалізації податкової реформи / за заг. ред. T. І. Єфименко, А. М. Соколовскої. К.: ДННУ “Академія фінансового управління", 2013. 492 с.

10. Дубовик О. Ю. Гармонізація податкових систем в умовах глобалізації. Фінансова система України: проблеми та перспективи розвитку в умовах трансформачії сочіальноекономічних відносин. Севастополь, 2013. С. 25-27.

11. Ярема Б.П., Ролько А.В. Сучасна податкова система України: проблеми та перспективи розвитку. Причорноморські економічні студіï. 2018. Випуск 34. С. 171-175.

12. Радова О.В. Оподаткування в Україні: нововведення, тенденції та проблеми розвитку. Науковий вісник Ужгородського національного університету. 2018. Випуск 20, частина 3.

13. Щербань О.Д. Напрями удосконалення формування доходів місцевих бюджетів. Вісник економіки транспорту $i$ промисловості. 2013. № 41. С. 74-79.

14. Крисоватий А.І. Теоретико-організаційні домінанти та практика реалізації податкової політики в Україні. Тернопіль: Карт-бланш, 2015. 371 с.

Information about the author: Dmytro Mishchenko, Doctor of Sciences (Public Administration), Professor at the Department of State, Local and Corporate Finance, University of Customs and Finance 2/4, Volodymyra Vernadskoho str., Dnipro, 49000, Ukraine 